\title{
SOLETRAS

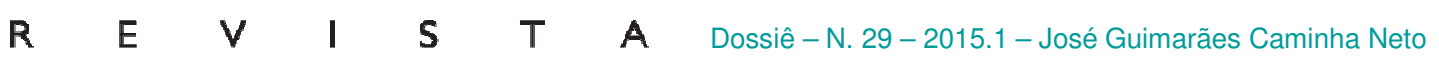

\section{O cavalo e a cadeira de balanço: um jogo de vai-e-vem entre Benjamin e Beckett}

\author{
José Guimarães Caminha Neto ${ }^{1}$
}

Universidade do Estado do Rio de Janeiro

\begin{abstract}
Resumo: Quando infante e na velhice, o homem experiencia no movimento pendular, no gesto de ir e vir, um jogo de dimensões temporais e espaciais. O cavalinho de balanço, feito de madeira, pode representar para a criança a conquista de um lugar no mundo, enquanto que, na cadeira de balanço, o adulto realiza a digressão e reúne as imagens que consegue buscar no passado pela lembrança e rememoração. Tanto o brinquedo (o cavalo) quanto o utilitário (a cadeira) tem seus valores de uso profanados, pela criança e pelo velho, e se reconfiguram tanto na brincadeira infantil quanto no jogo teatral. São lugares de passagem, encruzilhadas temporais em que o futuro sonhado e o passado rememorado aparecem de forma intempestiva. O pensamento de Walter Benjamin, em Reflexões sobre a criança, o brinquedo e a educação (2002), serve de ponto de partida as observações de Freud e de Giorgio Agamben. Na repetição dos gestos de outrem e no prolongamento do outrora, os personagens de Film (1963) e Rockaby (1981), de Samuel Beckett, tentam (re)montar a vida e buscam adiar o fim da partida.
\end{abstract}

Palavras-chave: Jogo. Gesto. Montagem. Morte.

A criança, nos gestos que realiza enquanto brinca, faz sinais e ordena. Reconfigura o mundo e dá-lhe novas possibilidades de sentido. Sem a fala, o infante pega, rasga, constrói e quebra. Existe, no jogo infantil, uma dimensão filosófica e poética, uma potência destrutiva e um impulso criador (AGAMBEN, 2008). A criança lida com os restos e, tendo-os em seu poder, lhes dá um novo uso a cada brincadeira. Por meio do gesto, ela não representa: joga e brinca. Esse gosto pela improvisação e o fato de o desempenho infantil orientar-se não pela "eternidade" do produto, mas sim pelo "instante" dos gestos, motivou Benjamin a afirmar que “enquanto arte efêmera, o teatro é arte infantil" (BENJAMIN, 2002, p. 117).

Nas mãos da criança, o lençol vira bandeira ou vela de um navio e a folha de uma árvore vira, pelo poder do faz de conta, um poderoso amuleto mágico. A brincadeira não se dá pelo conteúdo imaginário do brinquedo, por um objeto que procura ser igual a outro: os mais próximos do gesto de brincar são justamente aqueles que se distanciam da esfera da imitação.

\footnotetext{
${ }^{1}$ Mestre em Teoria da Literatura (UFPE) e doutorando em Literatura Comparada (UERJ). Desenvolve pesquisa na Itália, com bolsa da Capes, sob a orientação da Professora Dra. Carlinda Fragale Pate Nuñez (UERJ) e da professora Dra. Valentina Valentini (Università di Roma La Sapienza) sobre os conceitos de Pathosformeln, de Aby Warburg, e de imagem dialética, de Walter Benjamin, aplicando-os nas cenas criadas pelo dramaturgo e diretor Pippo Delbono para o teatro e o cinema. E-mail: josecaminha@gmail.com.
} 


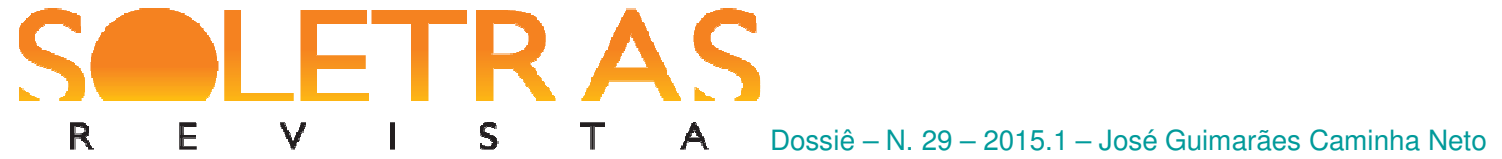

"Tanto mais autênticos quanto menos o parecem aos adultos" (Ibidem, p. 92), diz Walter Benjamin citando a Karl Gröber, para concluir adiante: "a imitação é familiar ao jogo e não ao brinquedo" (Ibidem, p. 93).

A assertiva se amplia quando a distinção entre jogar e brincar é problematizada tal como acontece na cena teatral, em que os participantes convivem entre as esferas do faz-deconta e das regras preestabelecidas, do texto e do improviso, entre outras peculiaridades da representação e do jogo teatral.

Da mesma forma que o ator "trai" o autor e o texto para construir o personagem, a criança aprende desde muito cedo a profanar as regras e objetos, encontrando para eles novas funções. O brinquedo é, portanto, a forma materializada de diálogo entre a criança e o adulto, entre a liberdade do poder tudo e a melancolia de não ser mais.

As observações de Walter Benjamin estão historicamente situadas num momento de grande virada tecnológica, quando o modo de produção industrial começa a substituir a manufatura e o artesanato. Benjamin, contrário à ideia de progresso, sugere, nas Teses sobre o conceito de História, de 1940, que é no ato de puxar o freio de emergência do trem em que viaja que a humanidade tem a possiblidade de promover a revolução. Neste trem descarrilado, o tempo e o deslocamento espacial não deixam para trás apenas um rastro de fumaça, pois também possibilita trazer de volta as imagens de um passado histórico. Nele, o cavalo se faz presente no quotidiano, na vida prática e na literatura e, ao realizar o gesto do galope, coloca o mundo em movimento. Metaforicamente, esta reflexão aproxima o cavalo da voz humana: quando o intercâmbio de propriedades simbólicas do tropel ou do refugo se põe em ação, num lugar entre o sagrado e o profano, é o cavalo que transporta pensamento. Afinal, até o final do século XIX, era atrelado ao cavalo que o homem conquistava seu lugar no mundo.

Domesticar o cavalo foi um dos primeiros desafios do homem. No que se refere ao cavalo de pau, de balanço (Fig.1), que surge como brinquedo no século XIX para as crianças, ele reproduz o movimento dinâmico da cadeira de balanço. Uma cadência para frente e para trás, um imóvel movente, que aproxima e afasta o olhar daquele que brinca - adulto ou criança - com os objetos ao redor. Parece óbvio que o animal, feito de madeira talhada, reproduz o processo de produção naquela sociedade do final do século XIX. Mas, entre pais e filhos, em que medida o brinquedo não traz no lombo o desejo de subordinação? Na miniatura do cavalo não estaria também a tentativa de domar a fala e sua potência negativa, a morte?

Walter Benjamin já havia chamado a atenção para a lei da repetição, que rege o mundo dos jogos. Para a criança, o "outra vez" possibilita dominar uma realidade e obter novamente 


\section{SOLTRAS}

o triunfo sobre uma situação; para o adulto, ao narrar uma experiência, a repetição "alivia o coração dos horrores" e permite experimentar de novo a felicidade; em comum entre eles, o fato de a brincadeira lhes proporcionar prazer e, portanto, estabelecer uma economia libidinal. Se há também, nessa compulsão, o desejo pelo restabelecimento de uma situação primordial, essa volta ao início não seria também um desejo de deter o tempo, de se debruçar sobre o passado, de encontrar na imagem antes abandona da algo que faz o mundo inteiro submergir? (BENJAMIN, 2002, p. 102).

Duas situações emblemáticas do jogo merecem ser lembradas e em ambas a figura referencial é a mãe. A primeira está em Carrossel (BENJAMIN, 1995, p.106), no qual a criança aparece, sendo colocada no lombo do cavalo dócil e mudo que o faz flutuar à altura do sonho. Ao som de uma música, o pequeno vai girando para bem longe da mãe e, depois de um passeio breve e de uma paisagem reconhecida, reencontra-a magnânima, reinando sobre aquele mundo onírico. A cada volta no brinquedo, o sentimento de segurança se renova. Quando o movimento e a música começam a ralentar, o carrossel vai perdendo o encanto, e só a mãe não perde a magia. Quando publicou Além do princípio do prazer, em 1920, Freud observara o próprio neto, então com um ano e meio. A criança estabelecia um padrão de repetição no qual encenava a ausência da mãe: ele jogava um carretel para fazê-lo desaparecer sob a cortina e dizia "ir embora" (em alemão, fort); depois puxava-o pelo fio, fazendo-o reaparecer, dizendo "ali" ( $d a)$, uma brincadeira de desaparecimento e retorno da figura materna. Elaborando esse jogo de repetição, nas duas situações, de acordo com Benjamin e Freud, a criança não faz o "como se" da representação, mas o "faz de novo" (mais afeito ao jogo). A diferença é que, no jogo do fort-da (lá-cá), ela assume o papel ativo e, ao jogar o carretel, escolhe o momento de ausência e de retorno da mãe, estabelecendo padrões distintos, de acordo com seu humor. Ao contrário do carrossel, cujo movimento depende de um mecanismo, no jogo do balanço (do cavalinho de madeira), existe também uma relação ativa, pois é a partir do movimento corporal da pessoa que o cavalo (ou a cadeira) se mexe.

Giorgio Agamben lembra que, tradicionalmente, o cavalo é identificado como elemento sonoro da linguagem. Em Ideia de cesura (1999, p.34), ele cita o filósofo Orígenes. O filósofo que viveu entre os séculos II e III comenta o décimo primeiro versículo do capítulo dezenove do Apocalipse, atribuído ao apóstolo João ("e vi o céu aberto, e eis um cavalo branco e o que estava montado nele chama-se fiel e verdadeiro, e julga a peleja com justiça”) para explicar que "o cavalo é a voz, a palavra como enunciado sonoro que corre com mais energia e velocidade que qualquer ginete" (Ibidem, p. 34). Seguindo esse raciocínio, são lembrados por 


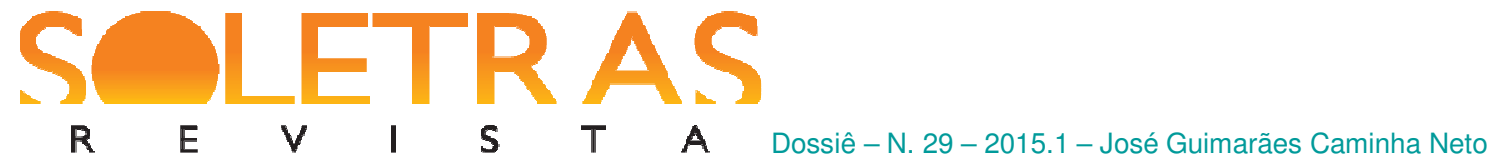

Agamben poetas como Guilherme de Aquitânia, Giovanni Pascoli e Sandro Penna, que encontram no cavalo o veículo no qual viaja a poesia. A voz do cavaleiro, o poeta, assume um ritmo. E o que divide o verso, a interrupção, a cesura, seria o pensamento.

A voz humana e o pensamento podem ser simbolizados de muitas maneiras, e a poesia pode alcançar um ritmo tão frenético que o fluxo de um pensamento sem rédeas dificulta a identificação da cesura. Em duas obras de Samuel Beckett, Film e Rockaby, a interrupção é problematizada, e o lugar da memória e da lembrança, em vez do cavalo, passa a ser a cadeira de balanço.

Sobre o cavalo de brinquedo, também objeto de uso doméstico, a criança lança um olhar profano sobre o lar: o quarto vira uma floresta encantada parecida com aquela do carrossel. Para ela, o brinquedo que balança é o ponto de fuga para um exílio voluntário, e as coisas que o circundam vão figurar como ruínas, imagens fragmentárias da memória do pequeno que se recompõem no jogo lúdico do ir e vir. Enquanto realiza a performance corporal de se balançar, a criança transita entre a perda e o abandono, pois sobre o cavalinho ela também passa a ser objeto desse mundo de coisas mortas.

A canção de ninar, que ajuda Samuel Beckett a elaborar um intrigante jogo de palavras e frases soltas a partir do ato prosaico de se balançar numa cadeira em Rockaby, conta a história de um berço que cai da copa de uma árvore. ${ }^{2}$ Ao reunir as temporalidades da infância e da morte, Beckett parece realizar em Rockaby (1981) o gesto de ninar um cadáver. As únicas imagens da encenação são centradas no rosto ou corpo inteiro, parcialmente iluminados, de uma mulher vestida de preto e sentada numa cadeira de balanço (Fig.2). A partir da inércia ${ }^{3}$, em quatro momentos distintos, a mulher levanta as pálpebras para dizer, na "abertura" de cada um desses quadros (e de forma cada vez mais sofrida), a palavra "more". Depois, volta a fechar os olhos e, ao se balançar na cadeira, faz a narração eclodir junto com o movimento. A súplica na voz da mulher aparentemente não inscreve o gesto na realidade imediata da cena, como uma reação àquele, pois tanto o movimento de uma cadeira de balanço quanto o fluxo do pensamento do sujeito não necessitam necessariamente de um impulso externo para se realizarem. Mas nada em Beckett deve ser resolvido de forma

\footnotetext{
${ }^{2}$ Rock-a-bye baby, in the treetop

When the wind blows, the cradle will rock

When the bough breaks, the cradle will fall

And down will come baby, cradle and all

(Rock-a-bye Baby)

${ }^{3}$ Já na cena de abertura pode-se reconhecer um memento mori que vai se repetir ao final de cada uma das quatro "estações" de Rockaby: em silêncio e de olhos fechados, a mulher deixa a cabeça pender para o lado, como se estivesse morta.
} 


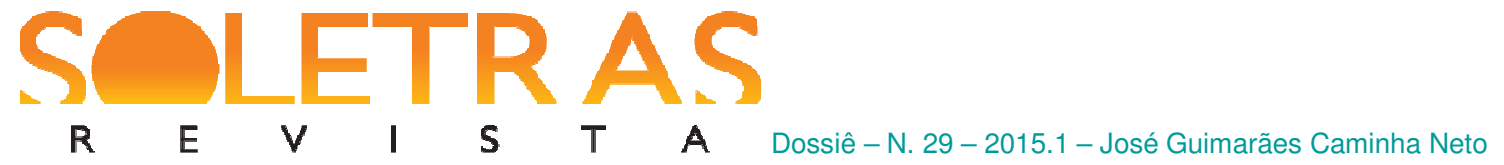

simplista. A voz que se ouve é gravada, e o movimento da cadeira, na cena, é realizado por um mecanismo instalado na sua base. Nesta configuração, Rockaby se distancia ainda mais da canção de ninar e ganha a aparência de uma mórbida caixinha de música que, em vez de louvar a juventude de uma bailarina, mostra a vacuidade de realizar um gesto qualquer enquanto se espera a morte.

Por outro lado, a performance da atriz Billie Whitelaw evoca uma dimensão extratemporal e paranomástica ${ }^{4}$. A fala remete ao pedido do menino órfão Oliver Twist (1838), do clássico homônimo criado por Charles Dickens, que tenta aplacar a própria fome e das outras crianças com mingau de aveia. A forma como a atriz pronuncia a palavra "more" confundindo-a com " $m a$ ", quase uma forma balbuciante de dizer "mother". Essa relação com a figura materna abre um amplo espectro para questões psicanalíticas e literárias através da imagem mítica de Demeter (ou Ceres, na mitologia romana), mãe de Perséfone ${ }^{5}$ (a Proserpina dos latinos).

Em cada um dos quadros de Rockaby, a dinâmica se repete: com o movimento realizado; o corpo surge, mais ou menos nítido, num jogo de desaparecimento e retorno, à medida que se expõe à luz. Ainda assim, a maior luminosidade não garante uma visibilidade completa da imagem, e o vulto daquela mulher é engolido pela escuridão com maior ou menor intensidade enquanto ela se balança, restando apenas, algumas vezes, o brilho tênue do strass do figurino, que faz o olhar do observador tentar reunir naquela poeira a forma original vista no momento anterior. A mulher se dissolve diante do espectador e, antes que o plano visual volte a atuar, sua imagem ressurge como trabalho de memória de quem acabou de vêla.

A cena se situa numa zona limiar: a voz, em off, está desprendida do corpo e é ainda mais isolada quando se percebe que se refere àquela imagem, como se falasse não para si mesma, mas dela. O pensamento, teatralizado na forma de um monólogo interior, é fragmentado em tempos, espaços e imagens. A voz, exilada daquele corpo, parece também um objeto que se perde e, vez por outra, volta ao locutor. Ela emana da escuridão e do extracênico, mesmo lugar em que se encontra o espectador.

O eu que fala, portanto, não é concreto e estável, impossibilitando formar, na cena, uma unidade articulada. A voz em off e a presencial se apresentam como dois personagens e só se

\footnotetext{
${ }^{4} \mathrm{Cf}$. em http://www.youtube.com/watch?v=G3cjRicX1Hw.

${ }^{5}$ Sobre esse tema, ver o artigo The Demeter Myth in Beckett Grace to breath that void. Know happinessBeckett, de Mary A. Doll, disponível em http://www.english.fsu.edu/jobs/num1112/109_DOLL.pdf. Acesso: $13 / 01 / 2015$.
} 


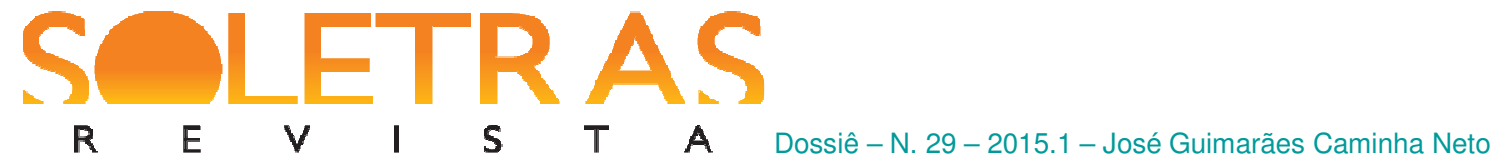

reúnem quando a frase "time she stopped" é dita. Neste momento, o embate entre o pensamento e o eu lírico se clarifica. No entanto, ao cessar o movimento, a personagem "perde" o seu lugar no mundo, pois é na esfera do pensamento que ela garante a sobrevivência. A repetição destaca, por um lado, um tempo de fadiga e desistência pontual, ao mesmo tempo que de resistência e apego à vida. Na solidão do palco, a única companhia daquela mulher é a sua própria voz, e ela carece profundamente desse "outro".

O cansaço da fala, o tom quase monocórdio, o ritmo intervalar quase idêntico com que dispõe as palavras como uma triste melodia são percebidos em Rockaby a partir de uma voz que, deslocada, transforma a mulher em objeto. O jogo de idas e vindas aproxima e afasta a mulher do ouvinte e do seu duplo ("another like herself / a little like" ou "another living soul / one other living soul'). A visualidade do palco e a extracênica é uma questão tematizada a partir do ato prosaico de usar uma cadeira de balanço: por todos os lados, acima e abaixo, os olhares se buscam e se reconhecem no mesmo vai e vem.

Ao perceber que está próxima do fim, a mulher volta-se para o passado, ao tempo em que, em vez da cadeira, ela sentava-se na janela para ver o mundo e ser vista. Um memento mori: ao final de cada uma das quatro "estações", ela silencia e deixa a cabeça pender um pouco, como se estivesse morta. Depois, abre os olhos, cada vez mais assustada, e pede "more" para, em seguida, de olhos fechados, tentar novamente se recompor a partir dos "cacos" da memória:

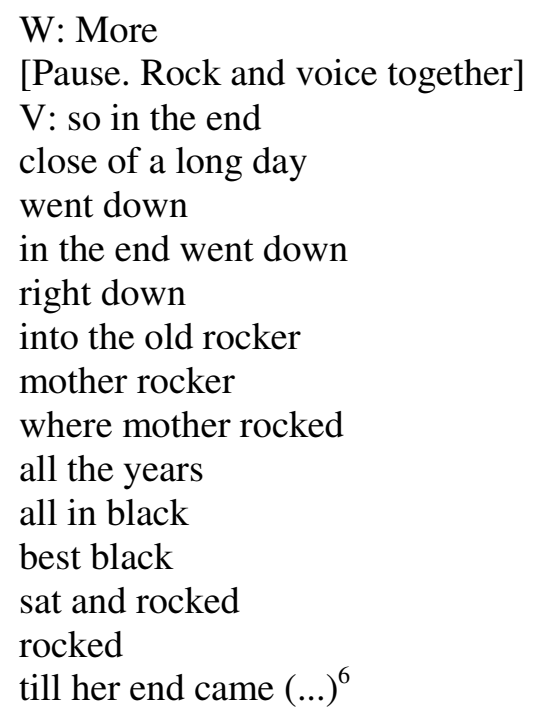

\footnotetext{
${ }^{5}$ M: Mais

[Balanço e voz juntos]

$\mathrm{V}$ : então no fim perto de um longo dia desceu no final desceu
} 


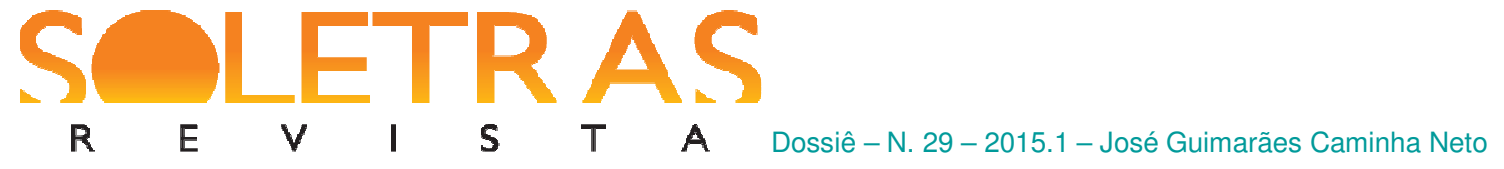

(BECKETT,1990).

Ao contrário da criança sobre o cavalinho, que consegue transformar o uso dos objetos que a cercam para elaborar, na imaginação, um mundo ideal, a mulher na cadeira de balanço fecha os olhos para rememorar o passado. A primeira pode se metamorfosear em qualquer coisa, à outra resta o luto pela perda da mãe, da juventude, da janela, dos olhares de outrem. A mulher aguarda cumprir o mesmo destino da mãe e, embora a cadeira seja impelida para trás, onde jazem as lembranças, não há como manter-se ali, pois o corpo acaba sendo deslocado para frente e para baixo, lugar do túmulo e do sótão, das coisas esquecidas. Em Rockaby existe também um tempo cronológico que é expresso pela decadência física. Aquela mulher tenta romper com este fio, apegando-se às imagens do pensamento. É impotente e segue, em linha reta, fiel à descida.

\section{Film: sob as rédeas do tempo e do desconhecido}

Se, em Rockaby, Samuel Beckett tenta problematizar o cogito cartesiano "penso, logo existo", dissolvendo a imagem do sujeito na cena e constituindo a fala por frases soltas e que emanam de temporalidades variadas, em Film (1963), sua única experiência cinematográfica, Beckett parece fazer uso do axioma "ser é ser percebido" (desdobramento da célebre fórmula "esse est percipi"), que sintetiza o Imaterialismo do filósofo e bispo irlandês George Berkeley, para apontar o ato de ver (e ser visto) como algo que pode significar uma ameaça à existência. $^{7}$

A percepção dos outros sobre o sujeito e também deste sobre si mesmo são temas recorrentes na obra de Beckett e se manifestam tanto na dimensão da escuta quanto da

\footnotetext{
direto para baixo

dentro da velha cadeira

cadeira mãe

onde a mãe balançava

todos os anos

toda de preto

no melhor preto

sentou e balançou

balançou

até que o fim dela veio [...]

(BECKETT, pag. 440, tradução nossa).

${ }^{6}$ A formulação completa de Berkeley seria: "Todos esses corpos que compõem a poderosa ordem do mundo não têm nenhuma subsistência sem uma mente - de modo que sua existência seja percebida ou conhecida".
} 


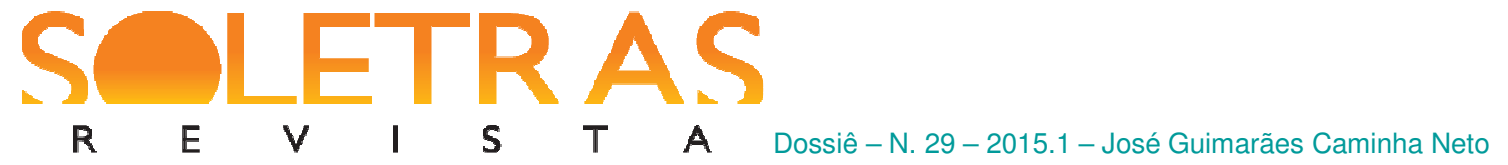

imagem. Ao se ouvir no gravador, em A última gravação de Krapp (1973), o protagonista devaneia, liga o aparelho novamente e registra: "Acabei de ouvir esse cretinóide por quem me tomava há trinta anos. Custa acreditar que eu já tenha sido desprezível a tal ponto (...)”. Em Rockaby, a complexidade da autopercepção se dá na escuta da voz que não se assume como parte constituinte do corpo e na imagem ambivalente da mulher que, num gesto voyeur, lembra do tempo em que se expunha à janela, na ânsia de ser notada: "olhos famintos como os seus, de ver, de serem vistos".

Em Film ${ }^{8}$, o desespero, a incompletude e a solidão se encontram na cisão do olhar. Buster Keaton, no papel de um homem que tenta desesperadamente não ser percebido, interpreta Object (Object ), sendo seguido de perto por Eye “("E”) (na verdade, durante a maior parte do filme, uma câmera subjetiva). Desde o início, Film tem a dinâmica de um jogo de perseguição, com Object completamente coberto, tentando se esconder das pessoas e fugindo dos olhares que lhe dirigem. Object consegue chegar a salvo na casa da mãe, mas os personagens com quem ele cruza no caminho (o casal da rua e a velha na escada) acabam ficando face a face com Eye. O casal reage com pavor e foge, enquanto a velha desfalece. ${ }^{9}$

A casa não é um refúgio de todo seguro. Ali, o personagem Object tem que evitar o olhar do peixe, do papagaio, do gato e do cachorro. Se sobre os dois primeiros basta lançar um pano escuro para evitar o olhar, expulsar os dois últimos não é uma tarefa fácil, e um rápido jogo de repetição e aparecimento/desaparecimento se estabelece quando Object expulsa um de cada vez e, ao abrir a porta, permite que o outro volte. O olhar para fora (a janela) e o olhar para dentro do ambiente (o espelho) são parcialmente evitados com uma persiana, velha e rasgada, e um pano preto. Soluções provisórias, pois a luz consegue entrar pela janela e, momentos depois, o tecido cai do espelho, obrigando Object a recolocá-lo no lugar com cuidado. A fotografia de um ídolo de madeira, de olhos de cavidades vazias, chamado por Beckett de Deus-pai, é arrancada da parede, rasgada e pisoteada. Dali, Object se vira e se depara com uma cadeira de balanço antiga, de madeira, localizada no centro da sala e que tem, sobre o encosto, um ornamento talhado em relevo, um par de olhos vazados, que parece olhar fixamente para ele.

\footnotetext{
${ }^{7}$ Ver filme completo em http://vimeo.com/20059827.

${ }^{8}$ Vale lembrar o estudo de Willy Hass, que identificou na "teoria gestáltica dos gestos lúdicos", o jogo de perseguição (gato e rato, polícia e ladrão, etc). Assim como a fêmea defende o ninho (tênis) ou se luta pela presa ou pelo osso (futebol), experimentamos alguns ritmos primordiais por meio dos quais nos tornamos senhores de nós mesmos (BENJAMIN, 2002, p.100-101).
} 


\section{SOLETR AS

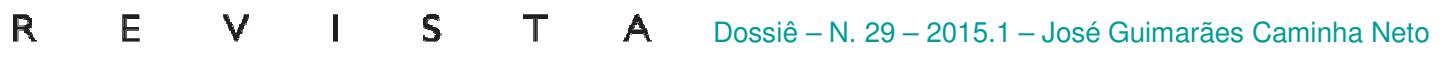

A imagem da cadeira remete, outra vez, a outras temporalidades para além do índice histórico imediato. Em vez de representar uma ameaça, estes olhos são como iscas para Object e, ao sentar-se na cadeira, o protagonista pode iniciar outra viagem, que traz de volta um passado distante e inacessível. A cadeira é o lugar do desejo e de passagem para o outrora. (Fig. 3)

Em Film, Beckett dota a cadeira de balanço de um poder questionador, e o gesto conciliador de Object de sentar-se é a aceitação do próprio destino. Esse pacto lhe permite expandir o olhar, caolho, até o infinito, e os olhos da cadeira, de órbitas vazias como as de um crânio, torna o homem, por instantes, parceiro de sela da morte. Percebe-se a dialética do próximo (a cópia fotográfica) e do distante (a realidade) que caracteriza o conceito de aura de Walter Benjamin num jogo no qual Object procura aproximar-se do que está fora do seu alcance (o tempo passado). A visão e o tato trabalham juntos para recuperar o tempo que, num primeiro momento, se desdobra de forma cronológica e sucessiva, para depois ser reapresentado numa sequência inversa, resultando na destruição de cada instantâneo.

A aura não está na cadeira de balanço, embora ela seja parte de Object. O enigma é o próprio personagem. Para desvendá-lo, Beckett coloca-o sobre aquele objeto mágico. A contemplação de si mesmo através das fotografias antigas estabelece também um jogo de aproximação e distância, pois Object é e, ao mesmo tempo, não é mais aquele que aparece nas imagens. Esse entrecruzamento simultâneo entre o passado e o presente é o que caracteriza o conceito benjaminiano de tempo e, nesta relação de reciprocidade, a possibilidade de redenção. As reminiscências em Film não parecem involuntárias, pois resultam de uma série de gestos que garantem a Object a possibilidade de rememoração.

Se a visão exige uma certa distância para a apreciação da fotografia, o gesto táctil trabalha de forma inversa. Object, ao deslizar os dedos sobre as figuras, percebe que aquele tempo está numa esfera impenetrável e inacessível. As imagens possibilitam as lembranças e, rasgando as fotografias, Object impõe o sujeito de hoje a si mesmo. Ele dorme na cadeira de balanço e, nesta tentativa desesperada de esquecer e destruir os vestígios do passado, percebe que não consegue fugir à autopercepção. Frente a frente consigo mesmo, Object cobre o rosto com as mãos. Ali ele se depara com a própria máscara mortuária e reatualiza o gesto de abrir o olho do início do filme (a fusão entre as imagens realizada na montagem do filme reforça essa ideia). Object fecha o olho, enquanto os dedos tocam a pele da pálpebra e as mãos cobrem o rosto, cuja textura enrugada lembra a superfície do muro. Depois da fuga inicial e, posteriormente, a chegada a um asilo, Object cumpriu o exílio e está pronto para o Nóstos. 


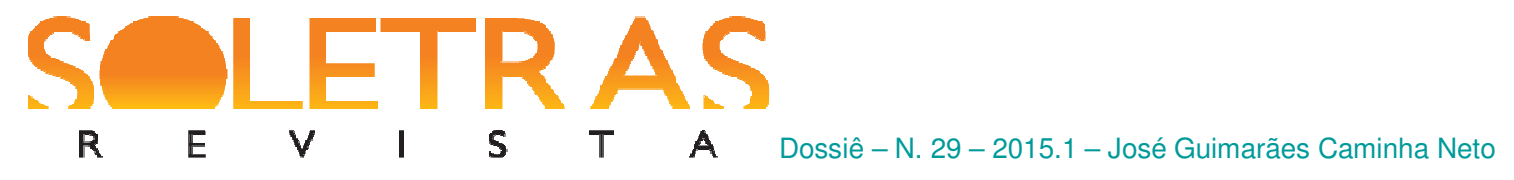

Este conceito, que em grego é o mesmo que "retorno", forma também a palavra "nostalgia" (dor de retornar). Se o conceito do Nóstos se enriquece com todas as narrativas de retorno, físico ou moral, político ou imaginário (incluindo uma vertente temática na literatura com a Odisseia de Homero), com Object o Nóstos ganha a imagem do grito mudo que o personagem realiza, no instante em que se depara consigo mesmo, diante do espelho. É a boca do Hades que se abre e o engole. A evocação do deus do mundo inferior, que é naturalmente ligado aos mortos, ganha visualidade nas escuridão emoldurada pelos lábios. São as trevas do reino do filho de Cronos, espaço de sombra, como as dobras do tempo que constituem a memória do personagem Object e, naquele mesmo instante fílmico, instaura, no presente, e a ideia de decomposição e finitude da matéria.

Se, sobre o cavalo de balanço, a criança descobre as potências da fala, do sonho e conquista um lugar mundo, ao longo da vida o sujeito se adapta às contingências impostas pelo meio, e o jogo passa a ser o de desaparecimento por trás da máscara social. Cômico ou trágico, às vezes gato, noutras rato, sobra pouco tempo para ser ele mesmo. No momento em que o cavalo assume a forma da cadeira de balanço, o sujeito percebe que é chegado o dia do julgamento. Nas imagens do pensamento (Rockaby) ou naquelas registradas no álbum de fotografias (Film), os fatos e personagens do passado retornam para exigir justiça. Os gestos captados dizem respeito apenas à vida de um indivíduo: são instantâneos de ações banais e quotidianas que, embora tenham índices históricos indiscutíveis, podem remeter a um tempo urgente e intempestivo.

O poder da imagem é, no entanto, dialetizado, quando o olhar do outro não garante a Objetct um lugar no mundo mas, outrossim, ameaça a existência dele, obriga-o a, vez por outra, tomar o próprio pulso e, neste memento mori, reconhecer-se vivo.

No balanço da cadeira, fazendo uma recapitulação progressiva da própria vida, Object vê as fotografias de quando era bebê e outra ainda criança ao lado da mãe. Na sequência, as imagens dele brincando com um cachorro, no dia da formatura, ao lado da companheira, com o filho nos braços (repetindo o gesto da mãe na primeira imagem) e a foto de si mesmo, já adulto, com olhar desafiador, direto para a câmera. As pessoas que ele deixou para trás cobram-lhe algo, mas Object tenta fugir dessa necessidade imperativa da lembrança, no que parece ser o próprio julgamento. Depois de assistir a um reprise cronológico de alguns fatos que se revelaram marcantes, Object remonta a vida em retrospectiva, da última para a primeira foto. Ele revê as imagens e rasga cada uma delas para, depois, tentar dormir para 


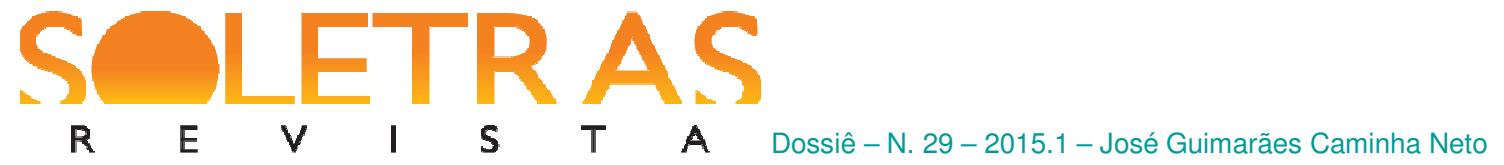

esquecer, com o passado e a imagem dele mesmo despedaçados e espalhados no chão do quarto. Eye, então, se põe de pé, do lado direito de onde estava a fotografia de Deus-pai.

Object assume o lugar sobre a cadeira, a mesma em que a mãe se embalava e de onde foi retirada para o leito de um hospital. Mais do que simplesmente lembrar, Object percebe, nas imagens que manuseia e sentado na cadeira, que realiza os mesmos gestos da mãe. As coisas da vida se revelam como repetições: o balanço é a condição limiar do humano que oscila entre os ritos de passagem, como o batismo, a formatura, o casamento e aquele, definitivo, que o fará deixar a condição de ser vivente para fazê-lo cadáver.

No movimento da cadeira está a nostalgia da infância perdida e, no gesto de se balançar, uma tentativa de fazer justiça à criança que se foi. Seja nos termos do tikkun da tradição messiânica judaica ou do equivalente cristão da apocatástase, o desejo de restabelecimento do estado original ilumina a promessa de um mundo novo. Por isso, voltar à sela daquele cavalo primevo é acreditar na utopia da alma, na salvação e na vida eterna - gesto ritual e lugar de passagem que não escapam ao olhar melancólico e poético de Beckett.

\section{Referências bibliográficas:}

AGAMBEN, Giorgio. Ideia da Prosa. Trad. João Barrento. Lisboa: Edições Cotovia Ltda, 1999.

Infância e História. Trad. Henrique Burigo. Belo Horizont: Editora UFMG, 2008.

Profanações. Trad. Selvino J. Assmann. São Paulo: Boitempo, 2007.

ATZINGEN, Maria C. V. A história do brinquedo: para as crianças conhecerem e os adultos se lembrarem. São Paulo: Alegro, 2001.

BERKELEY, George. The theory of vision vindicated and explained. In: BERKELEY, George. Philosophical Works. [ed. Michael R. Ayers]. London: Everyman, 1993.

BECKETT, Samuel. The complet dramatic works. London: Faber and Faber, 1990.

CAVALCANTI, Isabel. Eu que não estou aí onde estou: o teatro de Samuel Beckett. Rio de Janeiro: 7Letras, 2006.

BENJAMIN, W. Magia e técnica, arte e política: Obras Escolhidas I. Trad. Sergio Paulo Rouanet. São Paulo: brasiliense, 1994.

Rua de mão única: Obras Escolhidas II. Trad. Rubens Rodrigues T. Filho e José Carlos Martins Barbosa. São Paulo: Brasiliense, 1995. 
$\begin{array}{llllllll}\mathbf{R} & \mathbf{E} & \mathbf{V} & \mathbf{I} & \mathbf{S} & \mathbf{T} & \mathbf{A} & \text { Dossiê }- \text { N. 29-2015.1-José Guimarães Caminha Neto }\end{array}$

Reflexões sobre a criança, o brinquedo e a educação. Trad. Marcus Vinicius Mazzari. São Paulo: Duas Cidades; Ed. 34, 2002.

. Tentativas sobre Brecht. Madrid: Taurus, 1998.

DIDI-HUBERMAN, Georges. O que vemos, o que nos olha. Trad. Paulo Neves. São Paulo: Ed. 34, 1998.

DOLL, M. A. Walking and Rocking: ritual acts in Footfalls and Rockaby. In: DAVIS, R. J; BUTLER, L. St J., Eds. Make Sense Who May: Essays on Samuel Beckett's Later Works Gerrards Cross: Colin Smythe, 1988.

KAFKA, Franz. Um médico rural. Trad. e posfácio Modesto Carone. São Paulo: Companhia das Letras, 1999.

LOWY, Michael. Walter Benjamin: aviso de incêndio: uma leitura das teses "Sobre o conceito de história". São Paulo: Boitempo, 2005.

OTTE, G.; SEDLMAYER, S.; CORNELSEN, E. (Orgs). Limiares e passagens em Walter Benjamin. Belo Horizonte: Editora UFMG, 2010.

ROUANET, Sergio P. Édipo e o anjo: intinerários freudianos em Walter Benjamin. 3. ed. Rio de Janeiro: Tempo Brasileiro, 2008.

WEBB, Eugene. As peças de Samuel Beckett. São Paulo: Realizações Editora, 2006.

\section{The horse and the rocking chair: a play between Benjamin and Beckett}

Abstract: During infancy and in oldness, humans experience in the motion of the pendulum a set of temporal and spatial dimensions. The movement that people do while sat on a horse and on a rocking chair can help them to get a place in the world and make the exercise of digression. Benjamin's thought appears in this essay as a starting point for the observations of Freud and Agamben, which indicate that, on repeating the gestures of others and in the extension of past time, Beckett's characters of Film (1981) and Rockaby (1963) try to (re)build life and delay the endgame.

Key words: Play. Gestures. Montage. Death.

Recebido em: 28 de janeiro de 2015.

Aprovado em: 01 de agosto de 2015. 